\title{
A Novel Bow-Tie Antenna with Triple Band-Notched Characteristics for UWB Applications
}

\author{
Abdoulaye Chaibo',2*, Assane Ngom ${ }^{1,3}$, Mahamoud Youssouf Khayal ${ }^{4}$, Kharouna Talla1, \\ Aboubaker Chedikh Beye ${ }^{1}$ \\ ${ }^{1}$ Groupe de Laboratoires de Physique des Solides et Science des Matériaux (GLPSSM), Département de Physique, Université \\ Cheikh Anta Diop de Dakar, Sénégal \\ ${ }^{2}$ Département des Télécommunications et Multimédia (DTM), Institut National Supérieur des Sciences et Techniques d'Abéché, \\ Tchad \\ ${ }^{3}$ Université Côte d'Azur, CNRS, LEAT, Sophia Antipolis, France \\ ${ }^{4}$ Centre National de Recherche pour le Développement (CNRD), N’Djamena, Tchad \\ Email: ^abchaibo@gmail.com, Assane.NGOM@unice.fr,mahmoud.ykhayal@gmail.com,kharounatalla@gmail.com, \\ acbeye@gmail.com
}

How to cite this paper: Chaibo, A., Ngom, A., Khayal, M.Y., Talla, K. and Beye, A.C. (2016) A Novel Bow-Tie Antenna with Triple Band-Notched Characteristics for UWB Applications. Journal of Electromagnetic Analysis and Applications, 8, 271-282. http://dx.doi.org/10.4236/jemaa.2016.81202 $\underline{5}$

Received: November 11, 2016 Accepted: December 17, 2016 Published: December 20, 2016

Copyright $\odot 2016$ by authors and Scientific Research Publishing Inc. This work is licensed under the Creative Commons Attribution International License (CC BY 4.0).

http://creativecommons.org/licenses/by/4.0/ c) (†) Open Access

\begin{abstract}
This paper presents the design of a compact bow-tie antenna with triple band notched characteristics for UWB applications. The proposed antenna can operate from 3.1 to $10.6 \mathrm{GHz}$ with VSWR $<2$. Three Complementary Split Ring Resonators CSRRs are placed on the bow-tie antenna where each CSRR rejects one specific band. The CSRR1 rejects the IUT service band $(8.025-8.4 \mathrm{GHz})$ centered at $8.1 \mathrm{GHz}$, the CSRR2 rejects the WLAN band $(5.15-5.85 \mathrm{GHz})$ centered at $5.6 \mathrm{GHz}$, and the CSRR3 rejects the band $(4.10-4.47 \mathrm{GHz})$ centered at $4.32 \mathrm{GHz}$. Compared with recent design, this antenna is more compact, and presents better simulation results of its characteristics. Our newly designed antenna is a potential candidate for application in UWB communication systems.
\end{abstract}

\section{Keywords}

Bow-Tie Antenna, Ultra Wide Band (UWB) Antenna, CSRRs, Notch Band

\section{Introduction}

The Ultra Wide Band (UWB) for wireless communication systems has received much attention since the allocation of $3.1-10.6 \mathrm{GHz}$ band for this standard in 
2002 by the Federal Communications Commission [1]. The UWB technology can cover multi standards applications, offering several advantages in terms of high data transmission rate with low power consumption, low cost and low complexity.

This technology faces enormous challenges including electromagnetic interference with existing narrowband microwave frequency, such as IEEE $802.16 \mathrm{Wi}$ MAX system (3.3 - 3.7 GHz), IEEE 802.11a WLAN system (5.725 - 5.825 GHz), downlink of X-band satellite communication $(7.25-7.75 \mathrm{GHz})$ and ITU service (8.025 - 8.4 GHz). To overcome the problems resulting from electromagnetic interference, UWB antennas are used with discrete band stop filters.

Different types of UWB antenna topologies with single, dual, triple or quadruple band notched characteristics have been designed and reported in the literature [2]-[10]. Most common among these topologies-related fabricationmethods are etching techniques of various slots with different shapes (U-Shaped, C-Shaped, nested C-shaped, L-Shaped, Split Ring Resonators-SRR, Complementary SRR...). They are located either on the radiating element, or on the feed line or on the ground plane. The total size of the used slot calculated at the intended notch frequency defines the band-notched function [2]. Such size is about a half of the guided wavelength.

In [3] [4], the authors proposed a UWB antenna with one band-notched function. The UWB antennas with dual band-notch were presented successively in [2] [5] [6] [7], triple band-notch in [8] [9] [10] and multiple band-notch in [11] [12] [13]. Recently, a new approach is a design of reconfigurable UWB antenna with SRRs and CSRRs for notch single/multiple band [14] [15].

In [6], two band-notches are obtained by embedding $\Gamma$-shaped stubs in the patch and a modified G-slot defected ground structure in the feeding line. In [7], the authors also used U-slot defected ground structure of the feeding line combined with an E-slot etched on the radiating element.

In [8], the authors are using one, two and three CCL (Capacitively-Loaded Loop) elements placed near the feed line to notch one, two and three band-frequencies. In [9], the same technique as [8] is proposed but with two Elliptic Single Complementary Split-Ring Resonators (ESCSRRs) to notch two band-frequencies and also place two Rectangular Split-Ring Resonators near the feed line to obtain the rejection of the third band-frequency.

In this paper, a simple bow-tie UWB antenna with triple band-notched characteristics is proposed and studied. By introducing three CSRRs in the radiation element, triple band-stop filter is achieved.

The bow-tie antenna is considered as a planar biconical antenna version, it has a symmetric structure for which the currents are mostly focused on the edges [16]. We have chosen this type of antenna because of its attractive radiation characteristics, its compactness and its lightness. It also has a dipole type radiation, omnidirectional in the $H$ plane. 
The CSRRs elements are optimized, by adjusting their positions and dimensions in order to reduce mutual coupling. The design procedures are given in section II. One design example, using the procedure and simulation data is described in section III. Although the band rejection procedure in this paper is applied to a bow-tie antenna, it could be employed to design other type of antenna. Note that all simulations presented in this work are conducted using Ansoft High Frequency Structure Simulator (HFSS 17.0) simulator.

\section{UWB Bow-Tie Antenna Design and Geometry}

The topologies of the proposed antenna with and without CSRRs are shown in Figure 1(a) \& Figure 1(b).
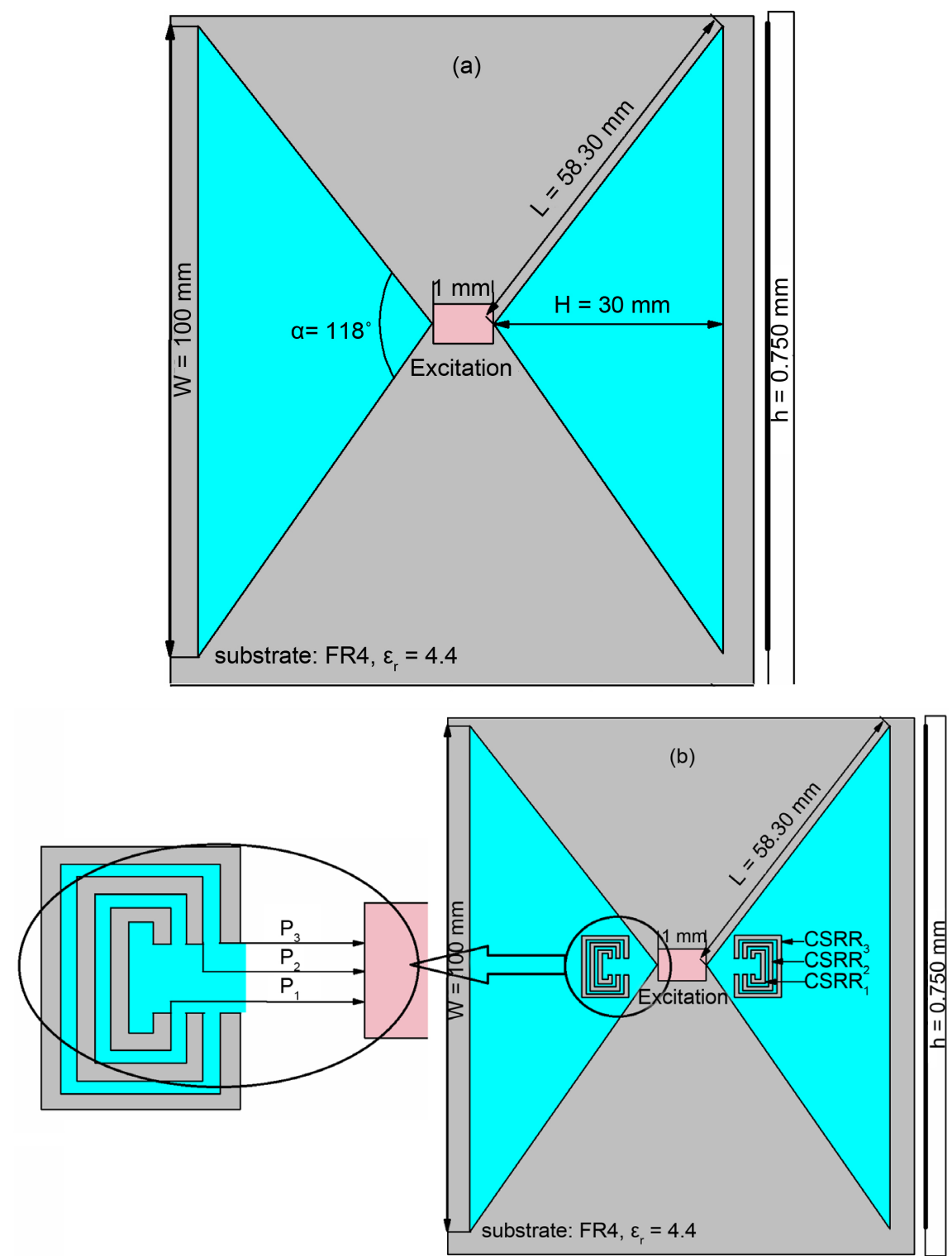

Figure 1. (a) Geometry of antenna without CSRRs. (b) Geometry of antenna with CSRRs. 
Bow-tie UWB antenna has been employed for many years in the VHF and UHF frequency ranges. However, the description of its behavior and its sizing are very fewly detailed in the literature. It consists of two triangles (characterized by the height $H$ and the flare angle $\alpha$ ) symmetrical with respect to the feeding point. The antenna is designed on FR4 substrate for $\varepsilon_{r}=4.4$ and loss tangent of 0.02 with thickness of $0.750 \mathrm{~mm}$ (Figure 1(a) \& Figure 1(b)). It is fed by a 50 $\Omega$ coaxial cable.

\subsection{Flare Angle $\alpha$ and Triangle Height $H$}

Small advances in the description of bow-tie UWB antenna were made by Balanis C.A. and Chen Z.N. who proposed respectively in [16] and [17] formulae that can be used to calculate the dimensions of the structures very close to the bow-tie antenna. Unfortunately, these formulae do not give concordant results in all cases.

Taking into account the above-mentioned remarks, and referring to the experimental work of Brown G.H. [18] on the triangular structure antennas, we used the formula (1) assuming that the flare angle is between $110^{\circ}$ and $140^{\circ}$ and that the first resonance is around $3 \mathrm{GHz}$.

$$
H=\frac{110}{360} \lambda=30.5 \mathrm{~mm}
$$

\subsection{CSRRs Dimension and Geometry}

Since the triangles are symmetrical and equipotential with respect to the feeding point, the CSRRs must be also symmetric with respect to the feeding point to have the same potential on the entire radiation element. That allows a good band rejection.

The various dimensions of the CSRRs cells determined according to the following formula (2) are shown in Figure 2.

$$
\frac{\lambda_{g}}{2}=\frac{c}{2 f_{\text {notch }} \sqrt{\varepsilon_{\text {eff }}}}=L_{\mathrm{CSRR}}
$$

In "Equation (2)", $\lambda_{g}$ is the guided wavelength, $c$ is speed of light in free space, $\varepsilon_{\text {eff }}$ is the effective dielectric constant and $f_{\text {notch }}$ represents the central frequency of the notched band.

$$
\begin{aligned}
& L_{\mathrm{CSRR}_{1}}=\frac{c}{2 f_{\text {notch }, 1} \sqrt{\varepsilon_{\text {eff }}}}=2\left(a_{1}+b_{1}\right)-G_{\mathrm{S}}=\frac{\lambda_{g, 1}}{2} \\
& L_{\mathrm{CSRR}_{2}}=\frac{c}{2 f_{\text {notch }, 2} \sqrt{\varepsilon_{\text {eff }}}}=2\left(a_{2}+b_{2}\right)-G_{S}=\frac{\lambda_{g, 2}}{2} \\
& L_{\mathrm{CSRR}_{3}}=\frac{c}{2 f_{\text {notch }, 3} \sqrt{\varepsilon_{\text {eff }}}}=2\left(a_{3}+b_{3}\right)-G_{S}=\frac{\lambda_{g, 3}}{2}
\end{aligned}
$$


(c)

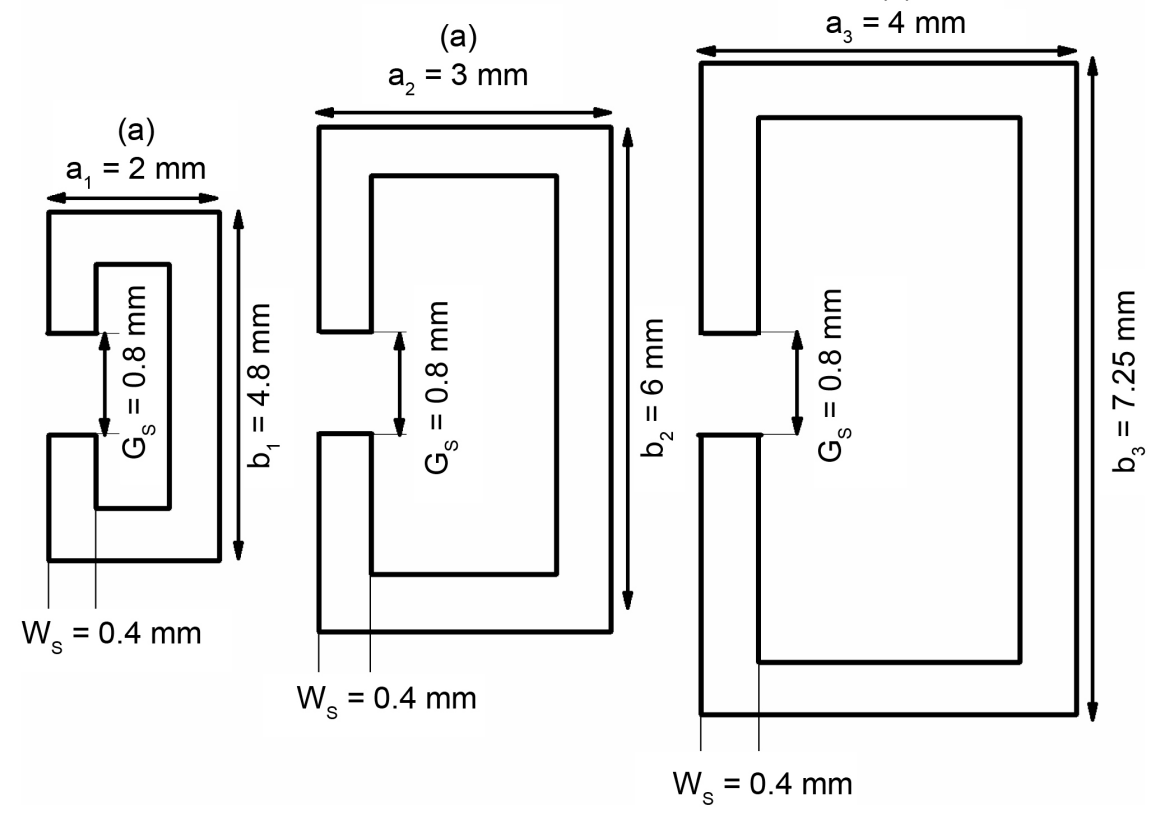

Figure 2. Geometry of CSRRs, (a): configuration for CSRR1 to notch $8.1 \mathrm{GHz}$ band; (b): configuration for CSRR2 to notch $5.6 \mathrm{GHz}$ band; (c): configuration for CSRR3 to notch $4.32 \mathrm{GHz}$ band.

\section{Result and Discussion}

The bow-tie antenna (Figure 1) is designed with the optimized parameters values listed in Table 1 such that it covers the entire FCC band from $3.1 \mathrm{GHz}$ to 10.6 GHz. The simulation result of the proposed antenna is shown in Figure 3.

At first, study was made only with a CSRR1 in bow-tie antenna. Insertion on both sides of the dipole is made not only to ensure symmetry (equipotentiality) between the triangles but also to improve the level of the frequency band rejection [16]. In his description of bow-tie antenna, it is shown that the currents are concentrated mainly on the edges. This implies that if the CSRRs cells are close to the feed point, there will be a better coupling thus allowing for good rejection of the solicited band. It should be noted that as the CSRR1 is close to the feed point, the band rejection level is excellent (VWSR $=8$ at $8.3 \mathrm{GHz}$ ). Furthermore, if the size (width) of the CSRR is increased, the band shifts towards lower frequency $\left(8.1 \mathrm{GHz}\right.$ if $\left.\mathrm{a}_{1}=2 \mathrm{~mm}\right)$. By a series of parametric study, the optimized value of the width and the position $\left(\mathrm{P}_{1}=3.2 \mathrm{~mm}\right)$ of the CSRR1 are determined. A good band rejection is obtained at $8.1 \mathrm{GHz}$. Figure 4 \& Figure 5 shows the effect of the CSRR1 position and width on the simulated VSWR of the prototype.

In a subsequent step, CSRR1 and CSRR 2 with bow-tie antenna were studied. The two CSRRs are nested for two reasons: the first is that we want to put both near the feed point in order to have a good level of frequency band rejection on every two CSRRs cells; the second is that CSRR2 is greater than CSRR1 


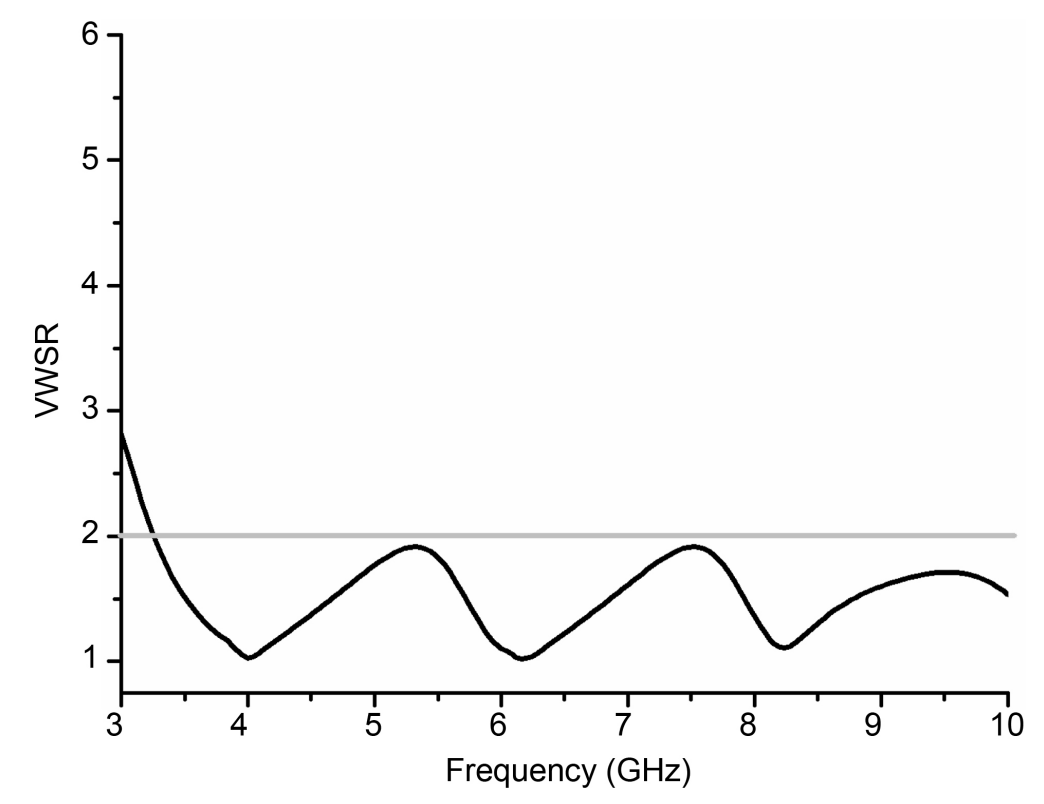

Figure 3. Simulated VWSR of antenna without CSRRs.

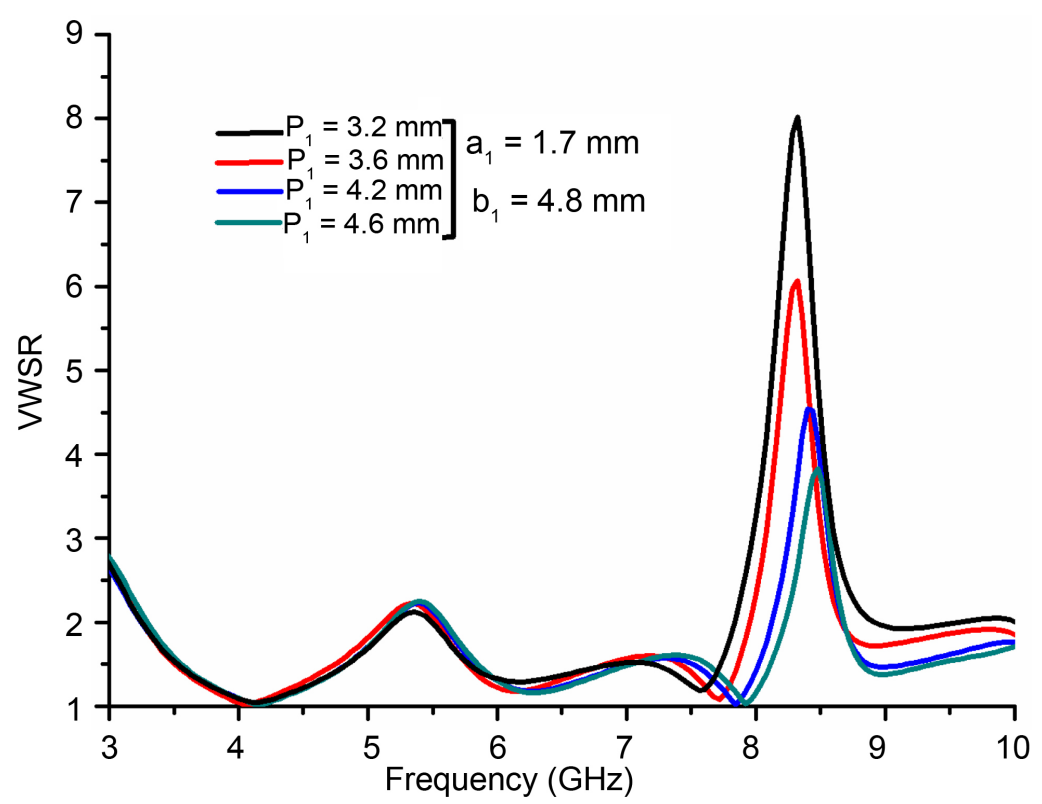

Figure 4. Simulated VWSR of the UWB bow-tie antenna with CSRR1: effect of CSRR position.

thus a cells nest allows us less clutter. A parametric study was made to investigate this effect on the influence of the positions of CSRR1 and CSRR2 ( $\mathrm{P}_{1}$ and $\mathrm{P}_{2}$ respectively). It is observed (Figure 6) that the optimal positions of the CSRRs elements are $\mathrm{P}_{1}=4.1 \mathrm{~mm}$ and $\mathrm{P}_{2}=3.6 \mathrm{~mm}$ with virtually VWSR $=5.20$ in both rejected bands centered at $8.1 \mathrm{GHz}$ and $5.6 \mathrm{GHz}$.

Figure 7 \& Figure 8 shows respectively return loss S11, radiation efficiency and Peak Gain of bow-tie antenna with two CSRRs. 


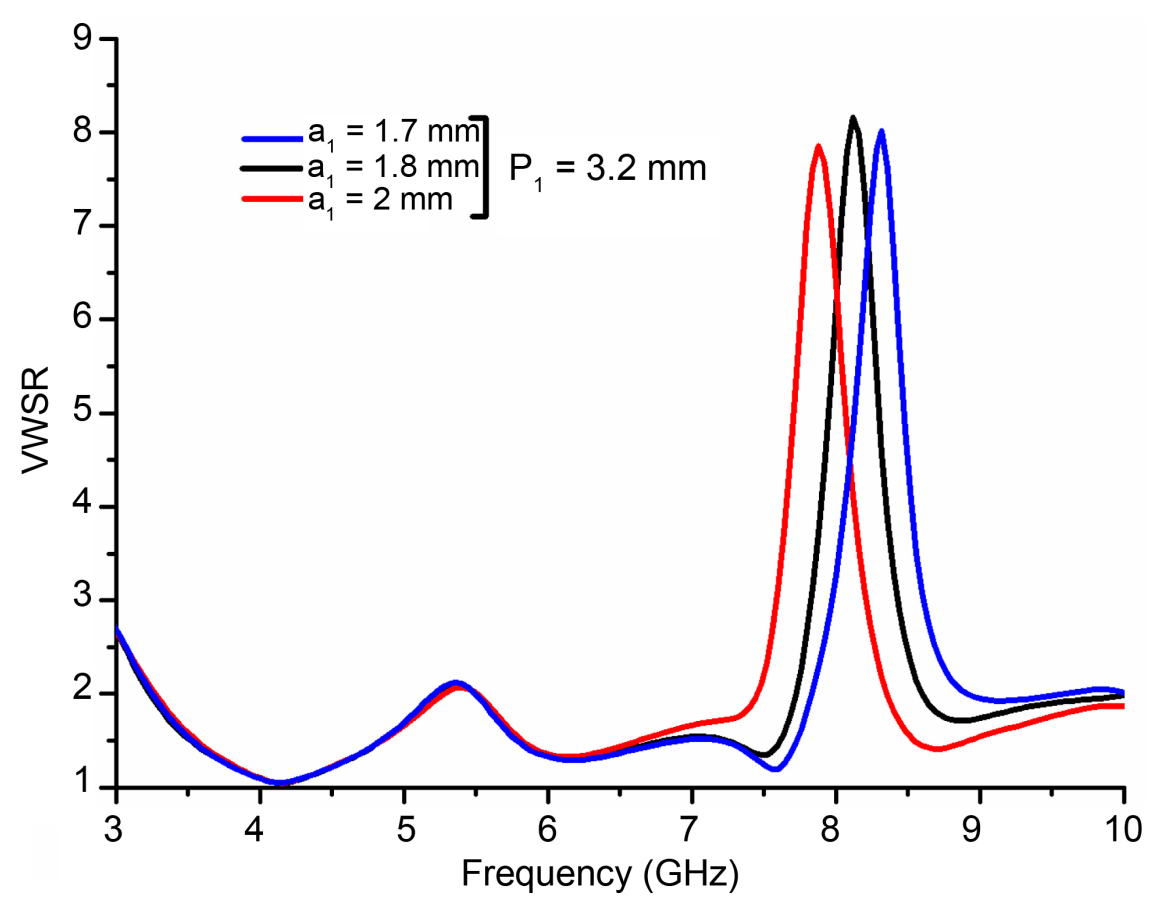

Figure 5. Simulated VWSR of the UWB bow-tie antenna with CSRR1: effect of CSRR size (width).

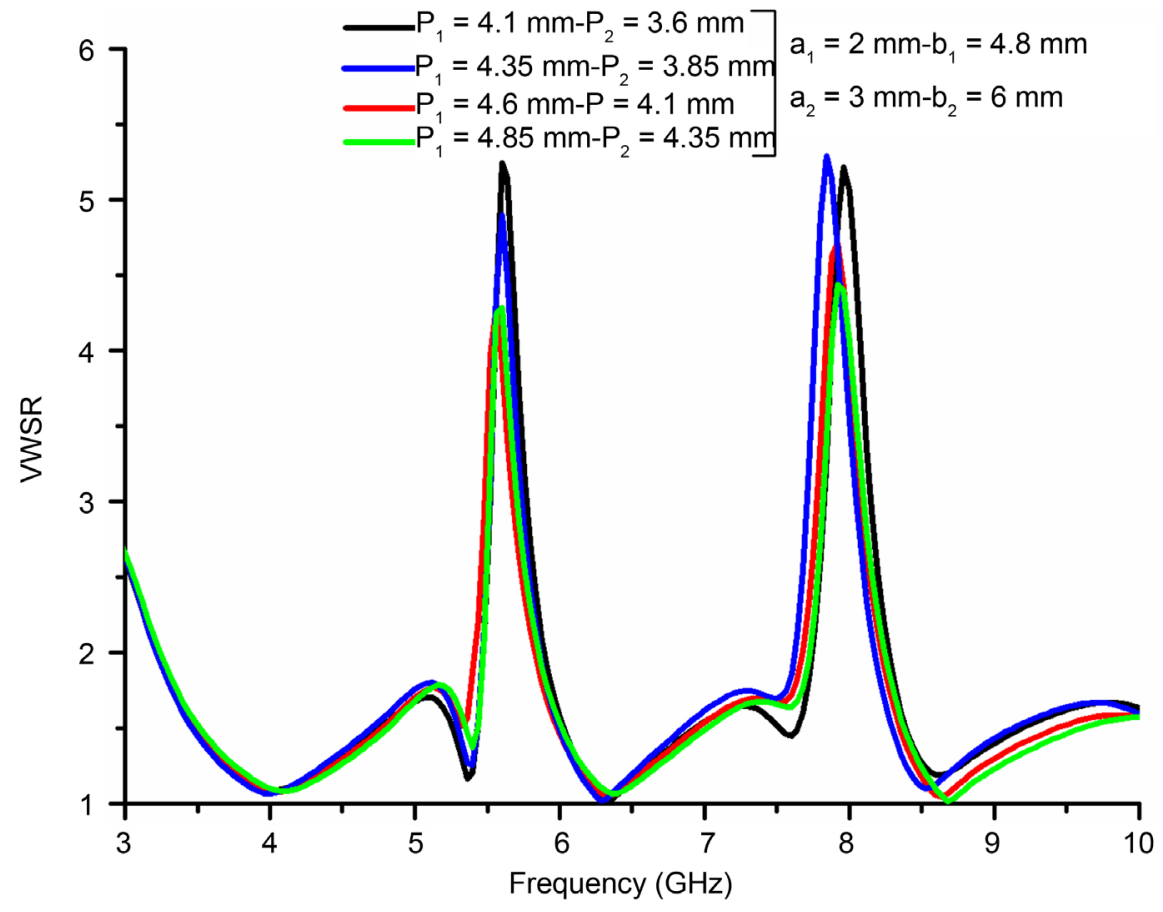

Figure 6. Simulated VWSR of the UWB bow-tie antenna with CSRR1 and 2: effect of CSRRs positions.

In a final step, CSRR1, 2 and 3 with bow-tie antenna was studied. For this step, the first two cells are remotely set by occupying positions $\mathrm{P}_{1}=4.6 \mathrm{~mm}-\mathrm{P}_{2}=$ 
Table 1. Parameters of bow-tie antenna with and without CSRRs.

\begin{tabular}{cccccc}
\hline Antenna parameters & $H$ & $W$ & $L$ & $h$ & $t$ \\
\hline Values $(\mathrm{mm})$ & 30 & 100 & 58.30 & 0.750 & 0.035 \\
CSRR1 parameters & $\mathrm{a}_{1}$ & $\mathrm{~b}_{1}$ & $\mathrm{Gs}$ & $W_{\mathrm{S}}$ & $L_{\text {CSRR1 }}$ \\
Values $(\mathrm{mm})$ & 2 & 4.8 & 0.8 & 0.4 & 12.8 \\
CSRR2 parameters & $\mathrm{a}_{2}$ & $\mathrm{~b}_{2}$ & $\mathrm{Gs}$ & $W_{\mathrm{S}}$ & $L_{\text {CSRR2 }}$ \\
Values $(\mathrm{mm})$ & 3 & 6 & 0.8 & 0.4 & 17.2 \\
CSRR3 parameters & $\mathrm{a}_{3}$ & $\mathrm{~b}_{3}$ & $\mathrm{Gs}$ & $W_{\mathrm{S}}$ & $L_{\text {CSRR3 }}$ \\
Values $(\mathrm{mm})$ & 4 & 7.25 & 0.8 & 0.4 & 21.7 \\
\hline
\end{tabular}

Where $W$ is the width of the triangles, $L$ is length and $h$ is the thickness, $\alpha=118^{\circ}$.

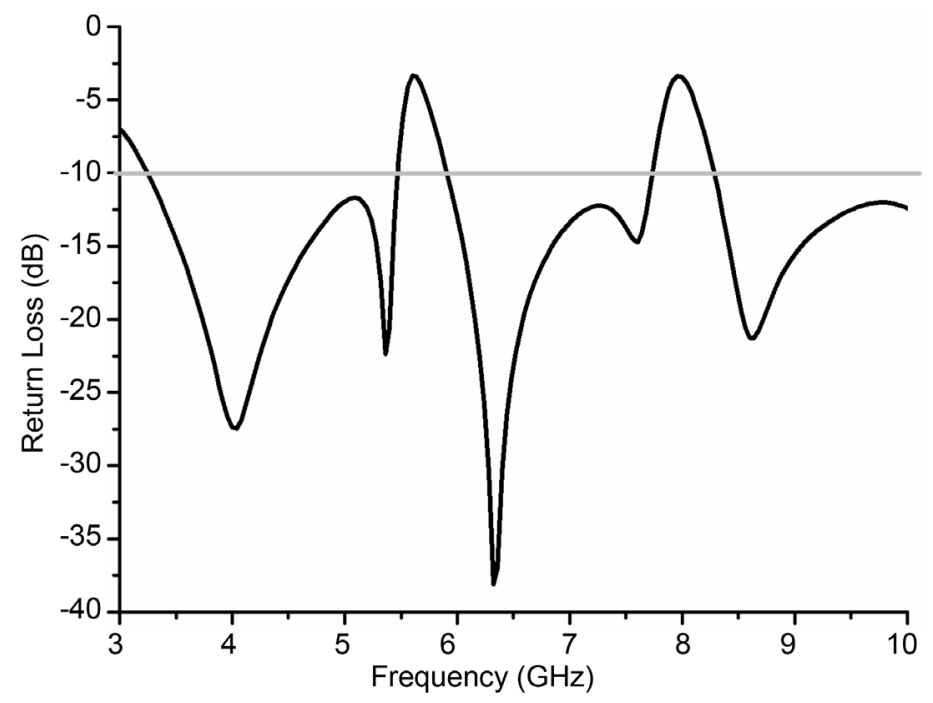

Figure 7. Simulated Return Loss of bow-tie antenna with two band notched characteristics: CSRRs optimized positions $\mathrm{P}_{1}=4.1 \mathrm{~mm}-\mathrm{P}_{2}=3.6$ $\mathrm{mm}$.

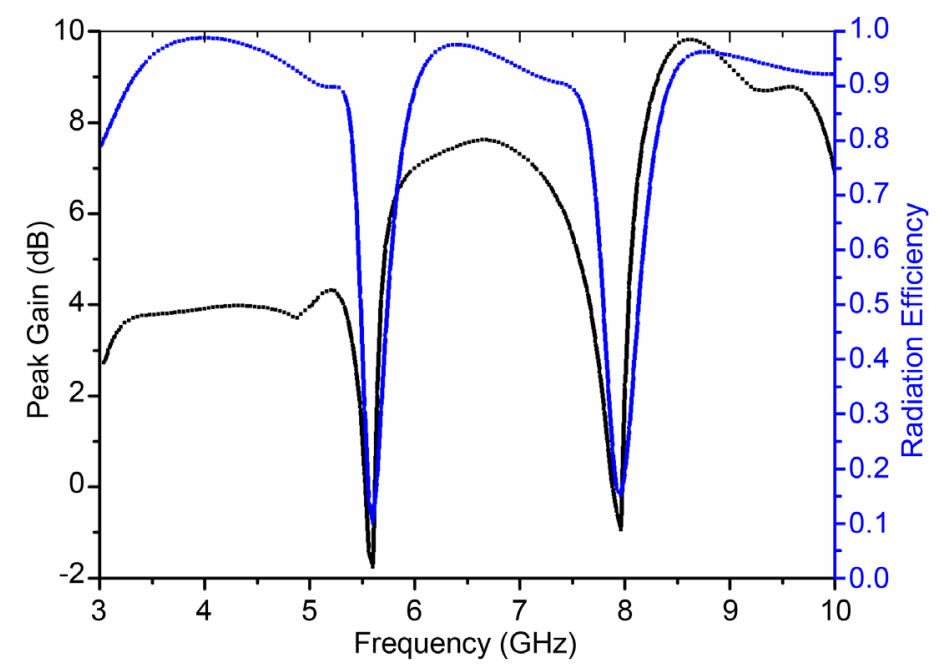

Figure 8. Simulated Peak Gain and radiation efficiency of bow-tie antenna with two band notched characteristics. 
$4.1 \mathrm{~mm}$ and leaving thus the third cell to $\mathrm{P}_{3}=3.6 \mathrm{~mm}$ position (shown in Figure (b)). Again, after a series of simulation and parametric studies, it is observed that this is the only position of the CSRRs where the bands rejection level is good.

Figure 9 and Figure 10 show VSWR and S11 parameter of the proposed antenna after optimization of CSRRs positions. The simulated gain and efficiency shown in Figure 11 also validate the triple band-notch behavior of the

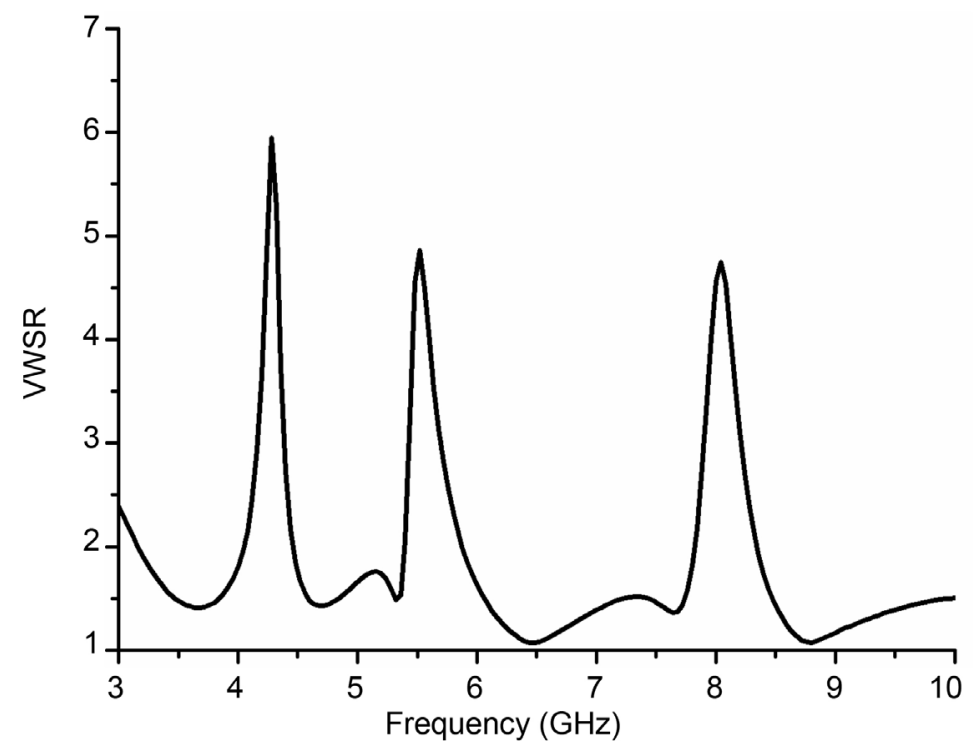

Figure 9. Simulated VWSR of bow-tie antenna with triple band notched characteristics: CSRRs optimized positions $\mathrm{P}_{1}=4.6 \mathrm{~mm}-\mathrm{P}_{2}=4.1 \mathrm{~mm}-\mathrm{P}_{3}=$ $3.6 \mathrm{~mm}$.

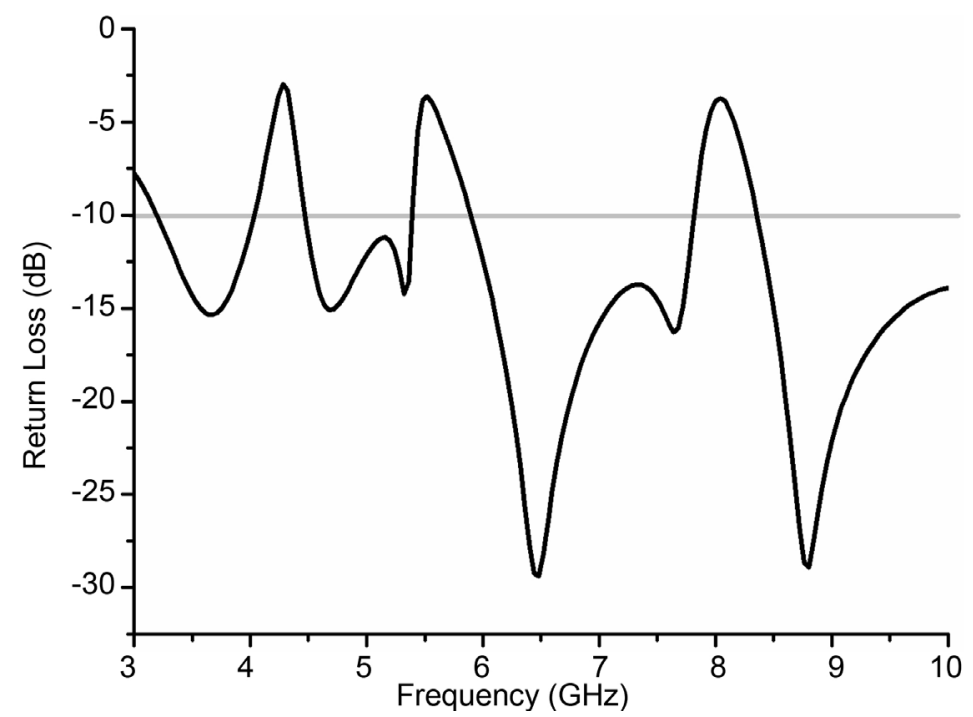

Figure 10. Simulated Return Loss of bow-tie antenna with triple band notched characteristics: CSRRs optimized positions $\mathrm{P}_{1}=4.6 \mathrm{~mm}-\mathrm{P}_{2}=4.1$ $\mathrm{mm}-\mathrm{P}_{3}=3.6 \mathrm{~mm}$. 


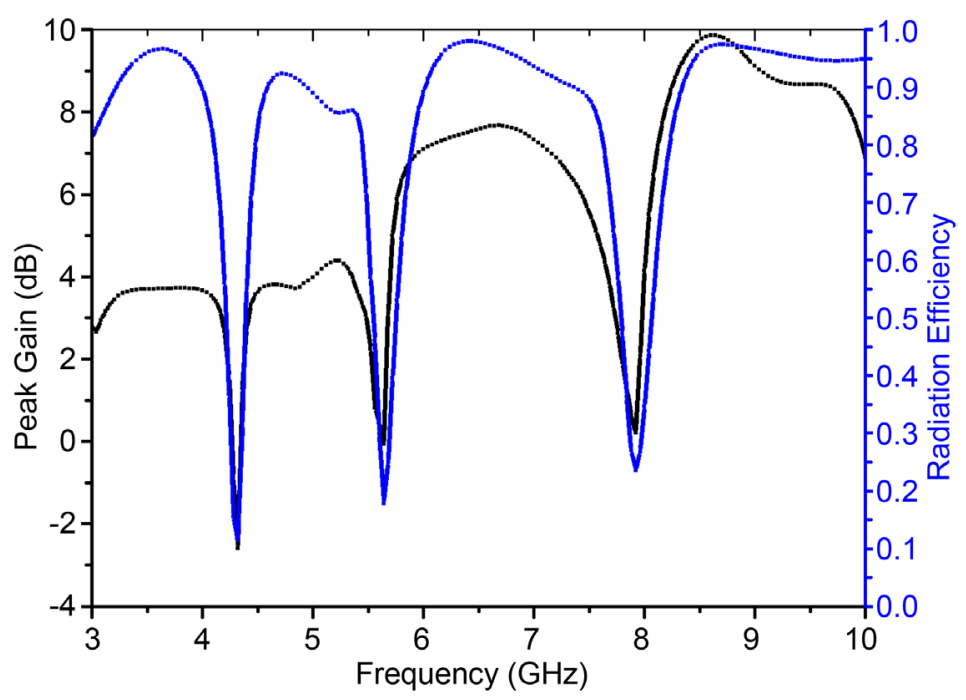

Figure 11. Simulated Peak Gain and radiation efficiency of bow-tie antenna with triple band notched characteristics.

proposed antenna. It is observed that for band-pass, the proposed antenna exhibits a nearly stable gain response.

\section{Conclusion}

In this letter, a compact triple band-notched UWB bow-tie antenna embedding Complementary Split Rings Resonators (CSRRs) in the antenna is presented. The proposed antenna has bandwidth covering the entire FCC range (3.1 - 10.6 $\mathrm{GHz}$ ), along with the band notched characteristics in the IUT service band (8.025 - 8.4 GHz), in the WLAN system (5.15 - $5.85 \mathrm{GHz})$, and another band frequencies $(4.10-4.47 \mathrm{GHz})$. The design and parametrical studies are described and validated via ANSYS EM simulations. VSWR, Return loss, Peak Gain, and Radiation efficiency triple-notch behavior of the proposed antenna. Stable antenna performance ensures that the proposed antenna can be utilized for various UWB applications with high immunity from electromagnetic interference.

\section{Acknowledgements}

The authors would like to thank the LEAT (Laboratoired' Electronique Antenneet Télécommunications) of the Nice Sophia Antipolis University available to them during their internship in the Ansys-EM simulation software. One of us, Assane Ngom, would like to thank the Agence Universitaire de la Francophonie for it financial support in the framework of their mobility program.

\section{References}

[1] Federal Communications Commission (2002) First Report and Order. Revision of Part 15 of Commission's Rules Regarding Ultra Wide Band Transmission Systems.

[2] Lee, W.-S., Kim, D.-Z., Kim, K.-J. and Yu, J.-W. (2006) Wideband Planar Monopole 
Antennas with Dual Band-Notched Characteristics. IEEE Transactions on Microwave Theory and Techniques, 54, 2800-2806. https://doi.org/10.1109/TMTT.2006.874895

[3] Hong, C.-Y., Ling, C.-W., Tarn, I.-Y. and Chung, S.-J. (2007) Design of a Planar Ultra Wideband Antenna with a New Band-Notch Structure. IEEE Transactions on Antennas and Propagation, 55, 3391-3397. https://doi.org/10.1109/TAP.2007.910486

[4] Vuong, T.-P., Ghiotto, A., Duroc, Y. and Tedjini, S. (2007) Design and Characteristics of a Small U-Slotted Planar Antenna for IR-UWB. Microwave and Optical Technology Letters, 49, 1727-1731. https://doi.org/10.1002/mop.22515

[5] Chu, Q.X. and Yang, Y.Y. (2008) A Compact Ultra Wideband Antenna with 3.4/5.5 $\mathrm{GHz}$ Dual Band-Notched Characteristics. IEEE Transactions on Antennas and Propagation, 56, 3637-3644. https://doi.org/10.1109/TAP.2008.2007368

[6] Abdollahvand, M., Dadashzadeh, G. and Mostafa, D. (2010) Compact Dual BandNotched Printed Monopole Antenna for UWB Application. IEEE Antennas and Wireless Propagation Letters, 9, 1148-1151. https://doi.org/10.1109/LAWP.2010.2091250

[7] Luo, L., Cui, Z., Xiong, J.-P., Zhang, X.-M. and Jiao, Y.-C. (2008) Compact Printed Ultra-Wideband Monopole Antenna with Dual Band-Notch Characteristic. Electronics Letters, 44, 1106-1107. https://doi.org/10.1049/el:20081548

[8] Lin, C.C., Jin, P. and Ziolkowski, R.W. (2012) Single, Dual and Tri-Band-Notched Ultrawideband (UWB) Antenna Using Capacitively Loaded Loop (CLL) Resonators. IEEE Transactions on Antennas and Propagation, 60, 102-109. https://doi.org/10.1109/TAP.2011.2167947

[9] Sarkar, D., Srivastava, K.V. and Saurav, K. (2014) A Compact Microstrip-Fed Triple Band-Notched UWB Monopole Antenna. IEEE Antennas and Wireless Propagation Letters, 13, 396-399. https://doi.org/10.1109/LAWP.2014.2306812

[10] Mohammadian, N., Azarmanesh, M.-N. and Soltani, S. (2010) Compact Ultra-Wideband Slot Antenna Fed by Coplanar Waveguide and Microstrip Line with TripleBand-Notched Frequency Function. IET Microwaves, Antennas \& Propagation, 4, 1811-1817. https://doi.org/10.1049/iet-map.2009.0367

[11] Li, L., Zhou, Z.L. and Hong, J.S. (2011) Compact UWB Antenna with Four BandNotches for UWB Applications. Electronics Letters, 47, 1211-1212. https://doi.org/10.1049/el.2011.2334

[12] Sharma, M.M., Deegwal, J.K., Kumar, A. and Govil, M.C. (2014) Compact Planar Monopole UWB Antenna with Quadruple Band-Notched Characteristics. Progress in Electromagnetics Research C, 47, 29-36. https://doi.org/10.2528/PIERC13121909

[13] Zhang, Y., Hong, W., Yu, C., Kuai, Z.-Q., Don, Y.-D. and Zhou, J.-Y. (2008) Planar Ultra-Wideband Antennas with Multiple Notched Bands Based on Etched Slots on the Patch and/or Split Ring Resonators on the Feed Line. IEEE Transactions on Antennas and Propagation, 56, 3063-3068. https://doi.org/10.1109/TAP.2008.928815

[14] Kandasamy, K., Majumder, B., Mukherjee, J. and Ray, K.P. (2015) Design of SRR Loaded Reconfigurable Antenna for UWB and Narrow Band Applications. IEEE International Symposium on Antennas and Propagation \& USNCI URSI National Radio Science Meeting, Vancouver, 19-24 July 2015, 103-104.

https://doi.org/10.1109/aps.2015.7304984

[15] Horestani, A.K., Shaterian, Z., Naqui, J., Martín, F. and Fumeaux, C. (2016) Reconfigurable and Tunable S-Shaped Split-Ring Resonators and Application in BandNotched UWB Antennas. IEEE Transactions on Antennas and Propagation, 64, 
3766-3776. https://doi.org/10.1109/TAP.2016.2585183

[16] Balanis, C.A. (1997) Antenna Theory Analysis and Design. 2nd Edition, John Wiley \& Sons Inc., Hoboken.

[17] Chen, Z.N. and Chia, Y.W.M. (2000) Impedance Characteristics of Trapezoidal Planar Monopole Antennas. Microwave and Optical Technology Letters, 27, 120-122. https://doi.org/10.1002/1098-2760(20001020)27:2<120::AID-MOP11>3.0.CO;2-D

[18] Brown, G.H. and Woodward, O.M. (1952) Experimentally Determined Radiation Characteristics of Conical and Triangular Antennas. RCA Review, 13, 425-452.

\section{Submit or recommend next manuscript to SCIRP and we will provide best service for you:}

Accepting pre-submission inquiries through Email, Facebook, LinkedIn, Twitter, etc. A wide selection of journals (inclusive of 9 subjects, more than 200 journals)

Providing 24-hour high-quality service

User-friendly online submission system

Fair and swift peer-review system

Efficient typesetting and proofreading procedure

Display of the result of downloads and visits, as well as the number of cited articles

Maximum dissemination of your research work

Submit your manuscript at: http://papersubmission.scirp.org/

Or contact jemaa@scirp.org 